\title{
Review of whole-farm economic modelling for irrigation farming
}

\author{
B Grové* \\ PO Box 339, Department of Agricultural Economics, University of the Free State, Bloemfontein, 9301, South Africa
}

\begin{abstract}
The main objective of this paper is to review the progress that has been made in South Africa with respect to whole-farm economic modelling over the past 2 decades. Farming systems are complex and careful consideration to the stochastic dynamic nature of irrigation farming processes and their linkages with the larger water system is necessary when conducting whole-farm modelling. Both simulation and optimisation approaches to whole-farm modelling have been developed. Simulation is able to realistically model key performance indicators for decision-making while taking cognisance of the stochastic dynamic nature of irrigation agriculture. Normally only a few predefined scenarios are considered and these do not include decisions regarding allocation of water between competing farm uses of water. Optimisation models take the opportunity cost of water into account while optimising water use between multiple crops. Simplifications of the soil-cropwater subsystem are necessary to optimise agricultural water use between activities which are differentiated by crop, irrigation technology and soil at whole-farm level. Appropriate use of crop simulation models to provide input for mathematical programming models holds promise but needs to be weighed against the extra time needed to validate models and generate the required information. Research is necessary to determine the value of considering water as a stock resource compared to a situation where water use is optimised without considering water as a stock resource. Optimisation results indicated that it is profitable to irrigate larger areas with water saved from deficit irrigation and increasing irrigation efficiency. Relatively little research was done to demonstrate the externalities caused by irrigation farming under the current water policy. Future research should focus on developing integrated hydro-economic modelling frameworks that will incorporate irrigation externalities. Modelling decision-making by means of a single-attribute utility function is unsatisfactory and more research is necessary to improve understanding of the decision-making process to enhance whole-farm modelling frameworks that will assist farmers in making tactical decisions.
\end{abstract}

Keywords: whole-farm, irrigation farming, profitability, modelling, optimisation, simulation, hydrology

\section{Introduction}

South Africa is currently undergoing a phase of water allocation reform. While South Africa's National Water Act (Act No. 36 of 1998) and National Water Policy (1997) provide the legislative and policy framework for water allocation, they do not provide detailed strategies and approaches to promote equity, sustainability and efficiency in water use, or a process to roll this out across the country. A complicating factor is that currently half of the water management areas are experiencing water deficits, while the country as a whole is in surplus. Furthermore, estimates show that the country's status will change in the near future from water-scarce to water-stressed (Seckler et al., 1999). The current reality is that in many instances it is not practical or economically viable to transfer water from surplus to deficit areas, resulting in localised water scarcities. In addition, the potential options for supply augmentation are limited and attention will have to be given to managing the increasing imbalances between water requirement and availability through the use of water conservation and demand management principles (Backeberg, 2006). Water conservation and demand management relate to measures to improve the efficiency of water use and the reallocation of water from lower to higher benefit uses within or between water-use sectors. The

This paper was originally presented at the Water Research

Commission 40-Year Celebration Conference, Kempton Park,

31 August - 1 September 2011.

* To whom all correspondence should be addressed.

용 +27 (0)51 401-3359; fax: +27 (0)86 525-5398;

e-mail: groveb@ufs.ac.za implementation of water conservation and demand management would have some serious implications for irrigated agriculture, since it accounts for $62 \%$ of stored water use in South Africa, with Government arguing that in many instances the water use is highly inefficient (DWAF, 2004). The water conservation and demand management strategy for the agricultural sector makes it clear that the irrigated agriculture sector will be targeted as a source of water that can be made available to competing water users and the environment through the implementation of water conservation and demand management principles within the sector. Central to the strategy is the use of a pricing strategy as a powerful tool to reduce water demand and enhance water-use efficiency (DWAF, 2004).

A great deal of research has been commissioned and funded in South Africa in view of the development of decisionsupport systems to enhance efficient water use. These efforts have mostly concentrated on the development of models to estimate crop-water requirements with the aim of enhancing irrigation planning (Crosby and Crosby, 1999) and simulation models to enhance real-time irrigation scheduling whereby water applications are minimised to achieve maximum crop yields (Annandale et al., 1999). English et al. (2002) argue that a paradigm shift is necessary to manage agricultural water use in future. The new paradigm would mean that irrigation applications would be based on economic efficiency principles rather than on the application of irrigation water to achieve maximum crop yield. Optimising water use based on economic principles implies taking into consideration all the relevant costs and revenues and the opportunity cost of water (scarcity value) while allowing the crop to sustain some level of water stress, resulting in yield reductions due to deficit irrigation. 
Many farm-level variables, such as irrigation technology, crop-water requirements, crop-yield response to water deficits, infrastructural constraints limiting water supply, credit availability and input and output prices of crops, will determine the opportunity cost of water. Generally, the interaction among these variables at farm-level is not well understood.

Two decades ago Backeberg and Oosthuizen (1991) reviewed present research and future challenges with respect to irrigation economics which entails the choice between alternatives to optimally allocate scarce resources. In their review they emphasised the need for a whole-farm modelling approach that takes cognisance of the stochastic and dynamic nature of irrigation problems and the importance of the farm manager as decision-maker. Even today, the whole-farm modelling approach is justified, since the likelihood of adopting new technologies or changes in management practices will be determined by comparing their impact on the allocation of scarce resources amongst all competing enterprises and fields at the whole-farm level while satisfying the objectives of the farm owner (Rodriquez et al., 2011). The main objective of this paper is to review the response of the research community through Water Research Commission-funded projects to conduct whole-farm level economic analyses of irrigation-related problems. More specifically, the review focuses on the efforts by researchers at the University of the Free State since these researchers have received continuous funding on the topic for the past 2 decades.

Next, the irrigation farm is discussed as a complex subsystem that is incorporated into a larger hydrological management system. The discussion highlights important factors that need to be considered in whole-farm economic modelling. The discussion is followed by a review of the research on the topic and some conclusions.

\section{A farm as a complex system}

Systems thinking (Spedding, 1988) is based on the notion that different subsystems form part of a larger system and that subsystems should not be studied in isolation. Rather, subsystems should be studied by taking their hierarchy into consideration within the entire system as well as the inter-relationships between subsystems. Figure 1 shows the irrigation farm as a complex system within a larger system. The irrigation farming system is part of the local water system governed by the wateruser association while the local water subsystem is embedded in the catchment water system which is governed by the catchment management agency. Governance within each subsystem is influenced by the natural environment (e.g. climate), economic environment and social environment.

The farm manager as decision-maker takes control of the irrigation farming system which might be divided into the soil-crop-water, capital, labour and management subsystems (Backeberg and Oosthuizen, 1991). To ascertain high overall farm productivity, the farm manager needs to allocate limited resources across different enterprises and fields at the wholefarm level to determine the optimal combination of management variables that influence crop production on a certain field (Rodriquez et al., 2011). Next, the 4 farming subsystems will be discussed in more detail.

\section{Soil-Crop-Water subsystem}

English et al. (2002) argue that irrigation based on economic efficiency principles will be the new paradigm that will govern irrigation management within the soil-crop-water subsystem in

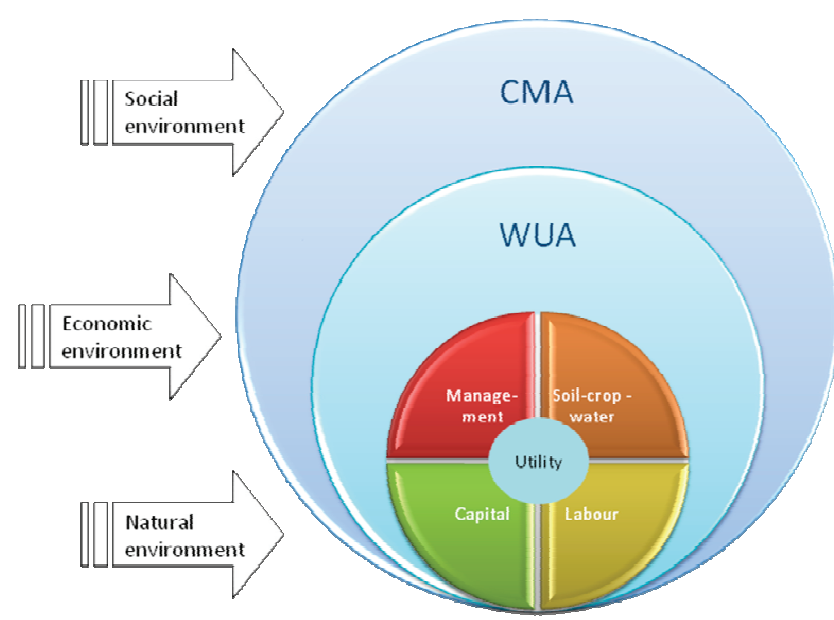

Figure 1

Systems approach to whole-farm modelling

future. The old paradigm where water was managed to achieve maximum yields will be replaced with one where water use between multiple alternatives is optimised to achieve economic efficiency. The change in paradigm is motivated by the increasing scarcity of water within the entire water system and more intense competition for water.

Irrigation optimisation should not be confused with scientific irrigation scheduling which relies on the systematic tracking of soil moisture or crop-water status to determine when and how much to irrigate (English et al., 2002). Scientific irrigation scheduling is typically done to minimise water applications with the aim of achieving maximum yield. Thus, no explicit consideration is given to costs, revenues and the opportunity cost of water. Optimisation of water use with the aim of maximising economic efficiency implies some form of deficit irrigation. Deficit irrigation is defined as an optimising strategy under which the crops are deliberately allowed to sustain some degree of water deficit, resulting in yield reduction in order to achieve maximum profit (English and Raja, 1996). Benefits of deficit irrigation derive from reduced operating cost, increased water-use efficiency and the opportunity cost of water. However, adoption of deficit irrigation is difficult and implies appropriate knowledge about crop evapotranspiration, yield response to water deficits, gross irrigation applications and the economic impacts of deficit irrigation (Pereira et al., 2002).

In order to optimise agricultural water use, one needs to relate applied water to some measure of crop-water consumption since consumptively used water is directly related to crop yield. Internationally, evapotranspiration (ET) is used most often in water-use optimisation studies as a measure of crop consumptive water use (Geerts and Raes, 2009; Cortignani and Severini, 2009). The reason is that ET formulae that relate crop yield to ET deficits, through the application of crop-yieldresponse factors $\left(K_{\mathrm{y}}\right)$, are well established (De Jager, 1994). Furthermore the $K_{\mathrm{y}}$ factors are available for a wide variety of crops (Doorenbos and Kassam, 1979) which facilitate application of the formulae. It is important to note that the relationship between applied water and ET is not linear. As more water is applied to satisfy ET, the relationship between applied water and crop yield becomes curvilinear due to increasing losses resulting from increased surface evaporation, runoff, and deep percolation (English et al., 2002). Thus, the relationship between crop yield and ET is more or less independent of soils, irrigation system, management and other factors that may 
influence the shape of the relationship between applied water and crop yield.

\section{Labour and Capital Subsystems}

The significance of the labour and capital subsystems in relation to the crop-soil water subsystem is that you need labour and capital investments to apply water to an irrigation field. Furthermore, capital may substitute for labour. Flood irrigation is labour-intensive while capital-intensive irrigation systems, such as drip and centre-pivot irrigation, require higher levels of management. Irrigation technology design, choice and management have a significant impact on the efficiency with which water can be applied (Ascough and Kiker, 2002).

Various researchers (Ascough, 2001; Li, 1998; De Juan et al., 1996; Mantovani et al., 1995) have demonstrated that the uniformity with which water is applied, and therefore the efficiency of the irrigation system, influences the curvature of applied water-yield relationships. High levels of uniformity are required to ensure that the major portion of an irrigation field receives an adequate water supply, which is a prerequisite for high crop yields with minimum loss of nutrients through deep percolation losses (Ascough and Kiker, 2002).

\section{Management Subsystem}

The responsibility of the farm manager is to integrate information regarding the various irrigation farming subsystems to allocate scarce resources on a whole-farm level in order to maximise his utility. The complexity of the soil-crop-water subsystem and the interaction with the other subsystems complicates the task of the decision-maker to a great extent.

Firstly, irrigation managers do not have direct control over ET but have control over the amount of water applied to satisfy ET. Inefficient water applications cause low water productivity. Water productivity could be increased by making capital investments in more efficient irrigation technology, maintaining irrigation technology to ensure high distribution uniformity and through proper irrigation scheduling at the field scale. The water productivity of the farm could be further increased by optimising water allocations between multiple crops and irrigation fields. The 'principle of equimarginal returns' or 'principle of opportunity cost' is the guiding economic principle that should be used to determine optimal allocation of irrigation water (Boehlje and Eidman, 1984). According to this principle, irrigation water should be allocated to its most profitable use such that the added return from the last unit of water will be the same across all alternatives.

Secondly, irrigation water is differentiated from other agricultural inputs in that crop yields are influenced by the stock of field-water supply (irrigation water stored in the root zone, effective rainfall, and soil-water carry-over) rather than the specific amount of water applied during a particular period of time. By implication, irrigation decisions during a given time period will influence water availability for crop production in subsequent time periods, which highlights the importance of taking the interdependency between water use in different crop growth stages into account when making water-allocation decisions. The importance of the interdependencies is furthermore exacerbated by the fact that water deficits in different crop growth stages will impact differently on final crop yield (Doorenbos and Kassam, 1979).

Lastly, the farming system is managed within a stochastic and uncertain environment due to climate variability and market volatility. The way a farmer manages the farming system may furthermore aggravate the risk they are exposed to. Irrigation water can be classified as a risk-reducing input. Reducing the amount of water that is needed to achieve maximum crop yield, will increase yield variability (Botes, 1990; Grové et al., 2006). English et al. (2002) argue that when the opportunity cost of water is taken into account and it is optimal to reduce water application and at the same time increase the area irrigated, any losses that may occur will be amplified by the increased area under irrigation. The risk tolerance level of the manager will ultimately determine the water-allocation decisions that will maximise his utility.

Viewing a farm as a complex system that operates within a larger hydrological water system has some implications for modelling water-management problems at the whole-farm level. Critical factors that need to be considered at farm level are the realism with which the soil-water-crop system is simplified, correct application of the principle of opportunity cost, the riskincreasing effects of deficit irrigation and the impact of adopting irrigation technology on water-application efficiencies. From a catchment management perspective it is important to consider the externalities (return flows and water quality) caused by irrigation farming. Next, the research commissioned and funded by the Water Research Commission (WRC) to enhance whole-farm modelling of irrigation-related problems is reviewed.

\section{Whole-farm simulation}

The whole-farm simulation approach to analysing irrigation farming profitability started with the research done by Oosthuizen and Meiring (1996) who developed a decision-support system to enhance risk-efficient decision-making in irrigation farming. Uninterrupted follow-up funding resulted in the development of the FARMS system of models (Meiring et al., 2002) comprising Windows-based computer programs to calculate irrigation cost, generate enterprise budgets, simulate cash flows and to incorporate risk into the analyses, with the ultimate aim of providing whole-farm decision support to irrigation farmers.

\section{Farms-Lotus}

The main objective with the development of FARMS-Lotus (Oosthuizen and Meiring, 1996) was to establish reliable and relevant information using well-established budgeting principles (Boehlje and Eidman, 1984) to enhance decision-making at the enterprise and whole-farm levels. As a point of departure, the model was developed in such a way that it could generate fund flows for any 4 crop enterprises and 2 livestock enterprises over a 12-month period. Originally FARMS-Lotus was developed as a LOTUS spreadsheet model. Computer capacity at the time had a significant impact on the structure of the model and it had to be developed using 3 separate modules comprising 2 files each. These files could not be linked together otherwise the risk simulations could not be conducted due to computer memory constraints at the time. As a result, macros were used to transfer data from one file to another before conducting the risk simulations. Although the aim was to develop a user-friendly model, only the data input and the representation of the results were well-structured, while generating the results was cumbersome due to the linking of the various components with macros.

Module 1 was developed to provide decision support at the enterprise level. Data-input requirements are grouped into 2 broad categories, namely general and enterprise specific. General inputs consist of the technological and economic 
parameters pertaining to farm machinery and irrigation systems and prices of all outputs produced and inputs used in the production process. Enterprise-specific inputs are concerned with specifying information regarding all the activities necessary to cultivate and irrigate fields, input purchases and produce sales. A distinction is made in the model between input costs that are dependent on crop yield, and costs that are area dependent. The time period in which each activity takes place must be specified and an indication of the specific account used to finance the activity must be given.

Results at the enterprise level consist of a detailed enterprise budget for each enterprise, use of funds during the 12-month period, mechanisation hours required, hours and amount of water pumped and the amount of labour hours required. At the whole-farm level information is aggregated for all the enterprises and displayed to aid decision support. FARMS-Lotus also provides separate fund flows for a credit account (cooperative) and a bank account.

Module 2 consists of input templates to characterise production risk, price risk and possible occurrences of hail damage using statistical distributions or empirical distributions. Information in Module 2 is used to conduct a risk simulation of cash flows. The main aims of Module 3 are to account for overhead costs that are not included at enterprise level and the provision of performance measures that are affected by risk. Module 3 is also used to capture the impact of interest rate variability on key performance indicators.

As part of the development of FARMS-Lotus, the model was used to evaluate irrigated crop-rotation diversification options, debt management and crop insurance as risk-management strategies. The risk efficiency of these alternatives was compared by means of stochastic dominance with respect to a function (SDRF) (Meyer, 1977). SDRF explicitly incorporates the risk-aversion level of the decision-makers when alternatives are compared. The researchers used the interval approach (King and Robison, 1981) that is based on SDRF rankings to elicit absolute risk-aversion ranges for the decision-makers.

\section{FARMS System}

The FARMS system (Meiring et al., 2002) was developed to upgrade, integrate and consolidate computer aids that had already been developed by the University of the Free State through funding by the WRC.

During the project, FARMS-Lotus (Oosthuizen and Meiring, 1996) was transformed into a Windows-based computer program. The functionality of the spreadsheet version of FARMS was retained, except for the risk-simulation component, which was removed and programmed as a separate computer program, RISKMAN. RISKMAN uses information contained in enterprise budgets and information regarding overhead cost to conduct a whole-farm budget for alternatives specified in the scenario manager. Furthermore, the model incorporates SDRF to discriminate between risk alternatives. The model is fully integrated with FARMS in the sense that it is able to import enterprise budget information from FARMS. It is essential to note that RISKMAN does not simulate a detailed cash flow such as the spreadsheet version of FARMS. The last model in the FARMS system of models is IRRICOST. IRRICOST is the Windows-based version of SPILKOST, which was developed to estimate the fixed and variable cost of centre-pivot and dragline irrigation cost. IRRICOST was subsequently further developed by Oosthuizen et al. (2005) to include cost-estimation procedures for micro-, drip- and furrow-irrigation systems. The cost-estimation procedures were not formally included in IRRICOST; rather a spreadsheet version of the model was developed.

\section{Water-use optimisation}

The optimisation approach used by Oosthuizen et al. (1996) to analyse irrigation problems was initiated simultaneously with the development of the simulation approach. In this section a distinction is made between research that optimises simulation models and research that uses simulation models to provide information for mathematical programming models of agricultural water use.

\section{Simulation optimisation}

The research done by Oosthuizen et al. (1996) specifically focused on determining the value of information that is generated with the aim to guide irrigation decisions by non-neutral decision-makers under limited and unlimited water-supply conditions on soils with different plant-available water-holding capacities. To achieve this objective, the researchers needed to represent as realistically as possible the stochastic dynamic environment in which irrigators make irrigation water-application decisions.

They argued that the dynamics captured within the soilcrop-water subsystem were best represented by crop-simulation models. Two crop-simulation models were evaluated for further use in the research, namely PUTU (De Jager and King, 1974) and the IBSNAT (IBSNAT, 1986) models. The IBSNAT model is an example of a true mechanistic model that simulates crop growth while PUTU uses a crop-yield-response function to calculate crop yield. After validating the models for 3 different crops, it was concluded that both models are suitable to evaluate the economics of maize production. The complex search algorithm (Kazmierczak, 1991) was linked to the IBSNAT maize model to optimise the soil-water depletion levels at which irrigation should be triggered to maximise utility. The IBSNAT model was preferred to the locally developed PUTU model due to incompatibility between the programming language of PUTU and the complex search algorithm. The resulting SIMCOM model was applied in Winterton to optimise the water use of a representative farm comprising 50 ha dry-land maize, 200 ha irrigated maize and 300 ha grazing utilised by the cattle enterprise. Six alternative irrigation-scheduling strategies, which used different levels of sophistication in terms of information regarding soils and weather, were optimised and compared to determine the value of the generated information.

It was found that the value of more sophisticated information has diminishing returns and that a relatively large percentage of the benefit of perfect information is accounted for by knowing the soil-water content. Results also showed that the value of information increased for soils with lower plantavailable water-holding capacities and when water is limited. Increasing levels of risk aversion tend to decrease the value of information compared to unlimited water-supply conditions.

\section{Mathematical programming}

Irrigators can respond in several ways to limited water availability. The SIMCOM model only considered irrigation scheduling as a response. However, irrigators may also change crop combinations, areas irrigated and irrigation technology. Including these options within the SIMCOM model may prove impractical due to the increase in the dimensionality of the problem in terms of the number of decision variables that need 
to be optimised simultaneously. As a result researchers have been in search of methods that would simplify the soil-cropwater subsystem to enable them to optimise irrigation water use between multiple crops at farm-level.

\section{Seasonal crop-water production functions}

An obvious choice for agricultural economists is to represent the soil-crop-water subsystem by means of a seasonal cropwater production function. Viljoen et al. (1993) used the PUTU (De Jager and King, 1974) model to simulate crop-water use and resulting crop yields for different crops in Vaalharts. The simulated information was used to estimate seasonal cropwater production functions. The seasonal water requirements of the different crops were disaggregated into monthly intraseasonal requirements before incorporating the data into their optimisation model to optimise water use, subject to intraseasonal water availability.

An implicit assumption made by this approach is that the intra-seasonal distribution of water across the growing season is optimal and technically efficient. Under these conditions economic theory suggests that water be allocated across crops in such a way that the value of the marginal product of applying water to a crop is equal to the cost of water plus the scarcity value of having a seasonal amount of water that needs to be allocated between crops (Willis, 1993). Introducing intra-seasonal constraints on the amount of water that can be applied due to irrigation system capacities, water-supply infrastructure capacities and irrigation-water availability change the optimality conditions to achieve an optimal allocation of water. When intra-seasonal water constraints are binding, water should be allocated in such a way that the value of the marginal product of applying water is equal to the cost of irrigation water plus the sum of the scarcity value of having a total seasonal water supply and the added scarcity value created by intra-seasonal water constraints (Willis, 1993). The implication is that the allocation of water need not be technically efficient. Thus, applying neoclassical production functions, which presuppose technical efficiency, to an intra-seasonal water-allocation problem will lead to non-optimal waterallocation decisions. To optimise intra-seasonal water allocation between multiple crops, a multi-period model is required where the impact of decisions in previous periods is linked to decisions during subsequent periods.

\section{Intra-seasonal models}

Mottram et al. (1995) adopted a procedure that will correctly optimise water use between multiple crops when intra-seasonal water allocations are limiting. The procedure relies on the inclusion of various activities consisting of different combinations of $10 \mathrm{~mm}$ deficits in each of the growth stages in their programming model. Crop yield was estimated for each combination using an additive law of calculating crop yield as a function of ET deficits. Two critical assumptions were made by these researchers. Firstly, they assumed that water use in any of the crop-growth stages is independent of the other. Thus, irrigation decisions made early on in the season have no influence on decisions made later on in the season. Secondly, they assumed that reductions in ET are proportional to reductions in applied water. Thus, these researchers did not model the non-linear relationship between applied water and crop yield resulting in increasing water-use efficiencies as the crop is deficit-irrigated. Results from their analyses indicated that deficit irrigation is not viable and that the areas planted should be reduced and fully irrigated. These results may be the direct result of the inability of these researchers' procedures to account for increasing irrigation efficiencies when the crop is deficit-irrigated.

Oosthuizen and Grové (2001) and Grové and Oosthuizen (2002) developed the ODI model (Optimised Deficit Irrigation) to optimise deficit irrigation while taking cognisance of increasing irrigation efficiencies as the crop irrigation deficit increases. Rather than generating discrete activities of alternative deficit irrigation schedules, these researchers optimised a continuous function that relates ET to crop yield. The Stewart multiplicative function has the property of modelling more than proportional yield reductions if the crop is stressed during more than one crop-growth stage (De Jager, 1994). Increasing wateruse efficiencies as the crop is deficit-irrigated were modelled using procedures developed by Willis (1993) whereby efficiencies are assumed to increase linearly between maximum water application and a given maximum allowed deficit. The results of the analyses indicated that it is profitable to practise deficit irrigation while spreading available water over larger irrigation areas. Although these researchers were able to model increasing irrigation efficiencies as the crop was deficit-irrigated, no link exists between the water budgets in different crop-growth stages. Furthermore, these researchers did not account for any changes in yield variability as the crop is increasingly deficit-irrigated.

During the early 2000s agricultural engineers in South Africa working in the field of irrigation highlighted the importance of the uniformity with which irrigation systems apply water on irrigation efficiency (Ascough, 2001; Ascough and Kiker, 2002; Lecler, 2004). Based on the work done by Lecler (2004), Grové and Oosthuizen (2010) incorporated the distribution uniformity with which water is applied into an Excel version of SAPWAT (Crosby and Crosby, 1999) by simulating 3 different water budgets. Each water budget received different amounts of applied water that was calculated as a function of the statistical distribution uniformity of the irrigation system. The modified SAPWAT model was used to simulate water use and crop-yield indices of 1296 different irrigation schedules for 3 different states of nature included in the SAPWAT weather database. The crop-yield indices were combined with subjectively elicited crop-yield distributions to characterise the crop yield associated with different irrigation technologies (see Grové, 2008 for details). The generated data were used in an optimisation model to optimally allocate water between 3 crops. Risk preferences were explicitly incorporated in the programming model through the maximisation of certainty equivalents. Maximising certainty equivalents for different levels of risk aversion produces a stochastic efficiency with respect to a function (SERF) efficiency frontier (Hardaker et al., 2004). Comparing the SERF efficiency frontiers of alternative scenarios yield the utilityweighted risk premium that a decision-maker needs to be compensated for when moving from the preferred alternative to a less preferred alternative. Absolute risk-aversion coefficients were chosen to correspond to maximum plausible levels of risk aversion as determined by Grové (2008). The result showed that deficit irrigation is stochastically more efficient than full irrigation under limited water-supply conditions due to the larger areas irrigated. It is imperative to note that larger irrigated areas imply that water saved by deficit irrigation is used to irrigate these areas and therefore water diversions are not reduced by deficit irrigation. Another approach was followed by Pott (2011) whereby the statistical function of distribution uniformity is explicitly incorporated into the optimisation model to model the relationship between applied water and consumptively used water. The consumptively used 
water is then used to estimate crop yield based on a cropyield-response function. Such an approach reduces the dimensionality of the programming model significantly. However, the approach does not take into account that irrigation water is a stock resource.

\section{Hydrology-linked economic modelling}

The main objective of hydrology-linked economic modelling is to more realistically model and quantify the impact of policies, institutions and catchment operating rules, insofar as they result in changes in water supply, on irrigation farming profitability and the hydrology of a catchment.

\section{Acru -Farms Lotus}

Irrigation farmers are able to control the water-supply risk they are exposed to by changing the area they irrigate. For a given water supply, the larger the irrigated area the less water will be applied on a per hectare basis, resulting in increased crop-yield risk. Oosthuizen and Grové (2001) used ACRU (Smithers and Schulze, 1995) to quantify the yield risk of a wheat crop when irrigating areas of varying sizes in Winterton. ACRU uses a predefined irrigation scheduling strategy to determine irrigation abstractions from the river for a specific sub-catchment. Through a modification, the water abstractions were restricted according to the water rights allocated to the sub-catchment. This enabled the quantification of crop-yield risk. The area irrigated and the resulting crop yields were used in FARMS-Lotus to quantify the cash-flow risk. Results from the analyses were subjected to a SDRF analysis to determine the risk-efficient area to irrigate for farmers with varying degrees of risk aversion. The absolute risk-aversion coefficients were taken from Botes (1990) without any adjustments. Results showed that the cash-flow risk of alternative areas planted to wheat was a direct result of the trade-off between the expected gain in income from irrigating larger areas and increased crop-yield variability associated with irrigating larger areas.

\section{Acru -ODI}

The ODI model (Oosthuizen and Grové, 2001; Grové and Oosthuizen, 2002) was linked to the output from ACRU to determine the economic cost of maintaining an environmental flow requirement under variable water-supply conditions in the upper Little Tugela River. Chance-constraints for monthly water availability were developed from the hydrological simulations to ensure that an environmental flow will be met at a specified probability level. The deterministic equivalents of the chance constraints were incorporated into the ODI model to determine the optimal response of the irrigators. No feedback loop from the optimisation model to the hydrological model that could determine the hydrological consequences of farmers' response was included in the modelling procedure. However, the results from the optimisation model were used to calculate potential return flows as a function of irrigation efficiency. Results from these analyses indicated that deficit irrigation or an increase in water-application efficiency reduce water applications per hectare when the saved water is used to irrigate larger areas. Thus, the overall crop-water consumption increased while potential return flows were reduced. These results highlighted the importance of considering the hydrological implications of farm-level water conservation strategies.

\section{Acru-Basin-Optimisation}

An example of a more comprehensive integration of hydrological and agricultural water-use optimisation is the research done by Pott (2011). One of the main objectives of his research was to establish a hydrology-linked economic model that is able to evaluate the impact of water curtailments in the Crocodile River basin. During the course of the project it was argued that changes in the way water was managed in the catchment will significantly affect the assurance of irrigation water supply to irrigators. Thus, strong arguments were put forward that the modelling system must be able to realistically model the impact of any changes in the hydrology on irrigation farming profitability.

A modelling system was developed around MIKE BASIN (DHI, 2000) to achieve the objectives of the project. MIKE BASIN is a powerful tool for integrated water resource management. The model is centred on a spatial representation of water supply and demand within a catchment and the daily reconciliation of the supply and demand, given specified operating rules. Water supply in the catchment was captured through hydrological simulations using ACRU. Irrigation water demand can either be captured statically by specifying daily irrigation water requirements in a separate file or the requirements can be simulated dynamically during the MIKE BASIN simulations with the irrigation scheduling model included in MIKE BASIN. The option to specify daily irrigation requirements makes it possible to link the output from the water-use optimisation model with MIKE BASIN.

An iterative approach was adopted to model the impact of operating rules on irrigation farming profitability using the hydrology-linked economic model. During the first iteration the irrigation module was used to calculate the necessary input parameters for the optimisation model on a daily basis. The data was subsequently aggregated to a weekly basis. The weekly irrigation information was used in the optimisation model to optimally allocate water across 30 different irrigation fields over a period of 20 years. Each irrigation field is characterised by different sugarcane planting establishment dates, soil information and irrigation technology. A statistical function derived from the distribution uniformity of the specific irrigation technology was used to model the relationship between gross water applications and consumptively used water $(\mathrm{Li}$, 1998). With the first iteration total water use is constrained to the water right but without any intra-seasonal constraints on water use. The resulting weekly irrigation water-demand profile was disaggregated to daily values and used in a second iteration to reconcile the demand with water availability in MIKE BASIN. The purpose with the second iteration was to determine whether the optimised irrigation water-demand profile is still valid given intra-seasonal restrictions imposed on the system via the different operating rules in the catchment area. Results from the analyses demonstrated the ability of the modelling system to model the impact of catchment management operating rules, international and environmental flow requirements on the profitability of irrigation farming.

Modelling results indicated that the way environmental flow requirements are enforced will most significantly affect irrigation water availability and irrigation farming profitability. If water-use rights are curtailed to maintain environmental flow requirements, a water curtailment of $20 \%$ will reduce irrigation farming profitability to such an extent that it will not be profitable to produce sugarcane using current irrigation technologies. 


\section{Discussion and conclusions}

The discussion of the farm as a complex system has highlighted 4 important aspects that need to be considered when evaluating whole-farm modelling pertaining to irrigation. Firstly, irrigation farms constitute a subsystem that forms part of a larger system. Necessarily the inter-relationships between subsystems need to be considered. Secondly, modelling irrigation problems requires a good understanding and representation of the soilcrop-water subsystem within the modelling framework that is used. Thirdly, irrigation water has an opportunity cost because it is scarce. Thus, economic principles should be applied to guide the allocation of irrigation water between competing water uses in order to maximise profits. Lastly, the stochastic nature of the environment in which farm managers operate, requires an explicit consideration of risk.

Two very different approaches to whole-farm modelling are discussed in this paper. The simulation approach uses cropsimulation models to capture the stochastic dynamic nature of the soil-crop-water subsystem. Typically the output from the crop model is used in combination with whole-farm budgeting and risk-simulation techniques to simulate key performance indicators for decision-making purposes. The simulation approach is best suited when a few alternatives are studied in detail. A shortcoming of the simulation approach is that it does not take the opportunity cost of scarce resources into account. When resources are scarce, decisions need to be made regarding their optimal use. Due to the number of different ways in which scarce water supplies can be allocated between multiple crops at farm level, the use of simulation modelling is not practical. To economically evaluate a large number of alternatives, researchers have relied on optimisation techniques.

The SIMCOM application has demonstrated that crop-simulation models can be optimised thereby taking cognisance of the stochastic dynamic environment in which decision-makers have to make decisions. However, careful consideration of the assumptions of the application highlights its limitations. The only variable that was optimised is the level of water depletion at which a fixed irrigation amount was scheduled. Thus, only water use within the season of 1 crop with a fixed irrigation area was optimised. A typical water-allocation decision at farm level involves multiple crops that compete for a limited amount of water at a given point in time. Mathematical programming models have been developed to optimise water use between multiple crops. Care should be taken not to apply crop-water production functions to intra-seasonal water-allocation problems because such an approach will result in sub-optimal water allocations. Multi-period models are more suitable for intraseasonal water-allocation problems. Good presentation of the soil-crop-water subsystem is possible within a programming model, provided multiple crop-simulation runs are included in the programming model. Such approaches are also used internationally to optimise water use. The extra time needed to conduct multiple runs with the crop simulation models should be weighed against the disadvantage of modelling field-water supply in different time periods independent of each other as is the case when using crop-water response functions to optimise agricultural water use.

The review has shown that the main focus of researchers was on modelling the impact of limited water supply on irrigation farming profitability through the development of procedures to optimise agricultural water use at farm level. Research results have shown that it is economically rational to use water that is saved through deficit irrigation and increased water-application efficiency to irrigate larger areas. Currently water entitlements are based on the diversion of a certain amount of water for beneficial use. The problem is that the proportion of consumptively used water increases if irrigators irrigate larger areas thereby causing negative potential returnflow externalities. Much less research effort was devoted to integrated hydro-economic modelling that considers returnflow externalities. Future research should focus on developing integrated hydro-economic modelling frameworks that are able to demonstrate the impact of changing policy on irrigation farming profitability on the one hand, and on the other hand, the impact of irrigators' actions on water resources. It is anticipated that the need for such frameworks will increase with growing competition for South Africa's scarce water resources and climate change.

Research efforts over the past 2 decades have made significant progress to appropriately quantify risk, simulate the consequences of risky alternatives and the application of stochastic efficiency criteria to guide decisions between risky alternatives. Some researchers have also started to apply risk-modelling procedures to optimise agricultural water use. Apart from estimating risk aversion and applying it in risk-efficiency analyses, no research was done to truly understand the decision-making process of farmers. Most of the research applications were concerned with profitability, thereby neglecting the whole-farm financial feasibility of alternatives. An important tool to evaluate feasibility is a cash-flow analysis. A distinct characteristic of the risk-programming models used to optimise water use and RISKMAN is that their cash flows are highly aggregated when compared with the deterministic FARMS model. Advances in computer technology and software development have opened up new possibilities to integrate detailed cash-flow budgeting procedures with water-optimisation procedures. Future research should focus on establishing whole-farm optimisation frameworks that incorporate more detailed financial feasibility at the whole-farm level to assist decision-making.

\section{Acknowledgements}

The University of the Free State, specifically the researchers at the Department of Agricultural Economics, wish to convey their sincere gratitude for generous financial support from the Water Research Commission over a period of 20 years to conduct their research and to develop the human capital regarding whole-farm decision support.

\section{References}

ANNANDALE JG, BENADÉ N, JOVANOVIC NZ, STEYN JM and DU SAUTOY N (1999) Facilitating Irrigation Scheduling by Means of the Soil Water Balance Model. WRC Report No 753/1/99. Water Research Commission, Pretoria, South Africa.

ASCOUGH GW (2001) Procedures for Estimating Gross Irrigation Water Requirements from Crop Water Requirements. M.Sc. (Eng) thesis. School of Bioresources Engineering and Environmental Hydrology. University of Natal, Pietermaritzburg, South Africa.

ASCOUGH GW and KIKER GA (2002) The effect of irrigation uniformity on irrigation water requirements. Water SA 28 (2) 235-242.

BACKEBERG GR (2006) Reform of user charges, market pricing and management of water: Problem or opportunity for irrigated agriculture. Irrig. Drain. 55 1-12.

BACKEBERG GR and OOSTHUIZEN LK (1991) The economics of irrigation: Present research and future challenges. Proc. Irrigation Symposium, 4-6 June, 1991, Elangeni Hotel, Durban, South Africa. BOEHLJE MD and EIDMAN VR (1984) Farm Management. John Wiley and Sons. 806 pp. 
BOTES JHF (1990) An Economic Evaluation of Wheat Irrigation Scheduling Strategies using Stochastic Dominance (Afrikaans) M.Sc. Agric. dissertation. Department of Agricultural Economics, University of the Orange Free State, Bloemfontein, South Africa.

CORTIGNANI R and SEVERINI S (2009) Modeling farm-level adoption of deficit irrigation using positive mathematical programming. Agric. Water Manage. 96 1785-1791.

CROSBY CT and CROSBY CP (1999) SAPWAT - A Computer Program for Establishing Irrigation Requirements and Scheduling Strategies in South Africa. WRC Report No. 624/1/99. Water Research Commission, Pretoria, South Africa.

DE JAGER JM (1994) Accuracy of vegetation evaporation formulae for estimating final wheat yield. Water SA 20 (4) 307-314.

DE JAGER JM and KING KM (1974) Calculation of photosynthesis rate of a maize crop from environmental variables. Can. I.B.P. Res. Rep. pp. 321-338.

DE JUAN JA, TARJUELO JM, VALIENTE M and GARCIA P (1996) Model for optimal cropping patterns within the farm based on crop water production functions and irrigation uniformity. Agric. Water Manage. 31 115-143.

DWAF (DEPARTMENT OF WATER AFFAIRS AND FORESTRY, SOUTH AFRICA) (2004) Water Conservation and Water Demand Management Strategy for the Agricultural Sector. Department of Water Affairs and Forestry, Pretoria, South Africa.

DHI (2000) MIKE BASIN - A Tool for River Basin Planning and Management. User Manual for MIKE BASIN 2000. Danish Hydraulic Institute, Horsholm, Denmark.

DOORENBOS J and KASSAM AH (1979) Yield Response to Water. Irrigation and Drainage. Paper 33. Food and Agriculture Organisation (FAO), Rome, Italy.

ENGLISH M and RAJA SN (1996) Review: Perspectives on deficit irrigation. Agric. Water Manage. 32(1) 1-14.

ENGLISH MJ, SOLOMON KH and HOFFMAN GJ (2002) A paradigm shift in irrigation management. J. Irrig. Drain. Eng. 128 (5) $267-277$

GEERTS S and RAES D (2009) Deficit irrigation as an on-farm strategy to maximize crop water productivity in dry areas. Agric. Water Manage. 96 1275-1284.

GROVÉ B (2008) Stochastic Efficiency Optimisation Analysis of Alternative Agricultural Water Use Strategies in Vaalharts over the Long- and Short-Run. Ph.D. thesis. Department of Agricultural Economics, University of the Free State, Bloemfontein, South Africa.

GROVÉ B and OOSTHUIZEN LK (2002) An economic analysis of alternative water use strategies at catchment level taking into account an instream flow requirement. J. Am. Water Resour. Assoc. 38 (2) $385-395$.

GROVÉ B and OOSTHUIZEN LK (2010) Stochastic efficiency analysis of deficit irrigation with standard risk aversion. Agric. Water Manage. 97 (6) 792-800.

GROVÉ B, NEL FS and MALULEKE HH (2006) Stochastic efficiency analysis of alternative water conservation strategies. Agrekon 45 (1) 50-59.

HARDAKER JB, RICHARDSON JW, LIEN G and SCHUMANN KD (2004) Stochastic efficiency analysis with risk aversion bounds: A simplified approach. J. Agric. Resour. Econ. 48 (2) 523-270.

IBSNAT (INTERNATIONAL BENCHMARK SITES NETWORK FOR AGROTECHNOLOGY TRANSFER) (1986) IBSNAT Technical Report 5, Decision Support System for Agrotechnology Transfer (DSSAT), Documentation for IBSNAT Crop Model Input and Output Files, Version 1.0. Department of Agronomy and Soil Science, University of Hawaii, Honolulu. 53 pp.

KAZMIERCZAK RF (1991) Pesticide Regulatory Actions and the Development of Pest Resistance: A Dynamic Bioeconomic Model. Ph.D. thesis. Department of Agricultural Economics, Virginia Polytechnic Institute and State University, Blacksburg, Virginia, USA

KING RP and ROBISON LJ (1981) Implementation of the Interval Approach to the Measurement of Decision-Maker Preferences. Department of Agricultural Economics. Michigan State University, Michigan, US.
LECLER NL (2004) Performance of Irrigation and Water Management Systems in the Lowveld of Zimbabwe. Ph.D. thesis. School of Bioresources Engineering and Environmental Hydrology. University of Natal, Pietermaritzburg, South Africa.

LI J (1998) Modeling crop yield as affected by uniformity of sprinkler irrigation system. Agric. Water Manage. 38 135-146.

MANTOVANI EC, VILLA LOBOS FJ, ORGAZ F and FERERES E (1995) Modeling the effects of sprinkler irrigation uniformity on crop yield. Agric. Water Manage. 27 243-238.

MEIRING JA, OOSTHUIZEN LK, BOTHA PW and CROUS CI (2002) The Implementation of the FARMS System for Managing Decision-Making in Irrigation Farming Summary Report and User Guides. WRC Report No. 894/1/02. Water Research Commission, Pretoria, South Africa.

MEYER J (1977) Choice among distributions. J. Econ. Theor. 14 326-336.

MOTTRAM R, DE JAGER JM, JACKSON BJ and GORDIJN RJ (1995) Irrigation Water Distribution Management Using Linear Programming. WRC Report No. TT 71/95. Water Research Commission, Pretoria, South Africa.

OOSTHUIZEN LK and GROVÉ B (2001) Optimale Bestuur van Wisselvallige Waterbeskikbaarheid op Plaas- en Streeksvlak met Inagneming van Risiko en die Omgewing. WRC Report No. 645/1/01. Water Research Commission, Pretoria, South Africa.

OOSTHUIZEN LK and MEIRING JA (1996) Die ontwikkeling van ' $n$ Besluitnemingsondersteuningstelsel vir die Ekonomiese Evaluering van Risiko-Bestuur op Plaasvlak en die Toepassing daarvan in die Halfdroë Gebied Benede die PK Le Rouxdam. WRC Report No. 347/3/96. Water Research Commission, Pretoria, South Africa.

OOSTHUIZEN LK, BOTES JHF, BOSCH DJ and BREYTENBACH P (1996) Increasing Economic Efficiency of Water Use for Irrigation at Whole-farm Level in the Winterton Area. WRC Report No. 347/2/96. Water Research Commission, Pretoria, South Africa.

OOSTHUIZEN LK, BOTHA PW, GROVÉ B, MEIRING JA, MONKHEI MM and PRETORIUS IG (2005) Cost Estimation Procedures for Micro-, Drip- And Furrow-Irrigation Systems as well as Economic Analysis of the Relevant Irrigation Systems for Large- and Small-Scale Farmers In The Onderberg/Nkomaszi Region. WRC Report No. 974/1/05. Water Research Commission, Pretoria, South Africa.

PEREIRA LS, OWEIS T and ZAIRI A (2002) Irrigation management under water scarcity. Agric. Water Manage. 57 (3) 175-206.

POTT A (2011) Personal communication, 22 August 2011. Project leader,WRC Project No. K5/1805: 'Development and Testing of an Integrated Set of Models to Evaluate the Impact of Water Curtailments Decisions on Participant Farm Case Studies in the Crocodile Catchment'. DHI South Africa, Johannesburg.

RODRIQUEZ D, DEVOIL P, POWER B, COX H, CRIMP S and MEINKE H (2011) The intrinsic plasticity of farm businesses and their resilience to change. Field Crops Res. 124 157-170.

SECKLER D, BAKER R and AMARASINGHE U (1999) Water scarcity in the twenty-first century. Int. J. Water Resour. Dev. 15 (1/2) 29-42.

SMITHERS JC and SCHULZE RE (1995) ACRU Agrohydrological Modelling System: User Manual Version 3.00. WRC Report No. TT 70/95. Water Research Commission, Pretoria, South Africa. AM7-1 to AM7-21.

SPEDDING CRW (1988) An Introduction to Agricultural Systems ( $2^{\text {nd }}$ edn.). Elsevier Applied Science, Barking.

VILJOEN MF, SYMINGTON HM, BOTHA SJ and DU PLESSIS LA (1993) Vaalhartsstaatswaterskema: Ondersoek na die Finansiële en Ekonomiese Uitvoerbaarheid van die Vergroting van die Sekondêre en Tersiêre Besproeiingskanale. Department of Agricultural Economics, University of the Free State, Bloemfontein, South Africa.

WILLIS DB (1993) Modeling Economic Effects of Stochastic Water Supply and Demand on Minimum Stream Flow Requirements. Unpublished Ph.D. thesis. Department of Agricultural Economics, Washington State University, Pullman. 